7. Reprod. Fert. (1974) 36, 135-139

\title{
OESTRADIOL-17ß: ITS INFLUENCE ON CYCLIC 3'5'-ADENOSINE MONOPHOSPHATE PHOSPHODIESTERASE AND 5'-NUCLEOTIDASE IN THE CERVICOVAGINAL EPITHELIUM OF NEONATAL MICE
}

\author{
M. G. HIGAZI* AND S. KVINNSLAND \\ Institute of Anatomy, University of Bergen, Bergen, Norway
}

(Received 22nd Fanuary 1973)

\begin{abstract}
Summary. This study concerns the histochemical demonstration of cyclic $3^{\prime}, 5^{\prime}$-adenosine monophosphate phosphodiesterase (cAMP-PD) and $5^{\prime}$-nucleotidase in the cervicovaginal epithelium of neonatal mice. Newborn animals showed no demonstrable activity of either of the enzymes; some cAMP-PD activity was present in 3-day-old animals, but no $5^{\prime}$-nucleotidase activity was seen at this age. Oestradiol-17 $\beta$ promoted an increased activity of both enzymes in 3-day-old animals. The localization of both enzymes was probably adjacent to the plasma membrane, with an increased activity at the luminal surface.

This investigation has shown that cAMP-degrading enzymes are present in this tissue and that the 'action mechanism' of oestradiol involves an effect on the cAMP-level regulating system.
\end{abstract}

\section{INTRODUCTION}

There is evidence that adenosine $3^{\prime}: 5^{\prime}$ cyclic monophosphoric acid (cAMP) is involved in the 'action mechanism' of oestradiol (Szego, 1971; Thompson \& Appleman, 1971a; Thomas, Czap, Ling \& Singhal, 1972). An increase in cAMP after administration of oestradiol (Szego \& Davis, 1967), a potentiation of oestrogen action by theophylline (Lafreniere \& Singhal, 1971), and simulation of oestradiol effects by exogenous cAMP (Sharma \& Talwar, 1970) all contribute to this view. Earlier reports from this laboratory (Kvinnsland \& Åbro, 1972; Kvinnsland, 1973) showed that the production of the specific cervicovaginal epithelial antigen, which is oestradiol-sensitive (Forsberg \& Kvinnsland, 1972), is enhanced by cAMP in an in-vitro system. It was of interest to study the occurrence and localization of the cAMP-degrading phosphodiesterase and to test the possible influence of oestradiol on this enzyme. The enzyme degrades cAMP to 5'-AMP which is attacked by 5'nucleotidase, and adenine is formed. The possible existence of a link between the activity of phosphodiesterase and 5'-nucleotidase was also examined.

\footnotetext{
* Present address: 17 Abdel-Hameed Abou Heif Street, Heliopolis, Cairo, Egypt.
} 


\section{MATERIALS AND METHODS}

Animals

The newborn female mice were of a randomly bred NMRI strain and were allowed free access to a standard pellet diet and water. The mice were allocated to two groups. Group 1 consisted of experimental animals which were given daily subcutaneous injections of $5 \mu \mathrm{g}$ oestradiol-17 $\beta$ (Sigma) in $0.02 \mathrm{ml}$ olive oil for 2 consecutive days after birth. Group 2 consisted of control animals which were given olive oil only. The vehicle was administered according to the same schedule as for Group 1. All animals were decapitated on Day 3, the cervicovaginal canal was dissected out and the preparations were immediately frozen in a jet of carbon dioxide snow.

Enzyme activity was studied in the newborn mice within $24 \mathrm{hr}$ after birth. The mice were given five injections of $5 \mu$ g oestradiol in olive oil for 5 days and were decapitated on Day 6. The cervicovaginal canals from these animals were processed as described above.

\section{Cryostat sectioning}

The preparations were sectioned at $10 \mu \mathrm{m}$ in a cryostat type Dittes-Duspiva at $-20^{\circ} \mathrm{C}$. The sections were mounted on slides and kept in the cryostat at $-20^{\circ} \mathrm{C}$ until they were processed further.

\section{Histochemical assay of cAMP-phosphodiesterase (cAMP-PD)}

The histochemical method of Shanta, Woods, Waitzman \& Bourne (1966) was used. Freshly prepared standard incubation medium (SIM) was composed of the following ingredients: (1) tris-maleate buffer, $\mathrm{pH} 7.6$ to $7.7\left(5 \times 10^{-2} \mathrm{M}\right)$, (2) magnesium chloride $\left(10 \times 10^{-3} \mathrm{M}\right)$, (3) lead acetate $\left(2 \times 10^{-3} \mathrm{M}\right),(4)$ snake venom (Crotalus atrox; Sigma), $0 \cdot 1$ to $1 \mathrm{mg} / \mathrm{ml}$ medium, was also added to the above mixture. This substance possesses high $5^{\prime}$-nucleotidase activity and was added to the medium to avoid a limiting step when 5'-AMP was formed by the phosphodiesterase activity.

The sections from the different animals were divided into three groups which were incubated as follows: (1) in $10 \mathrm{ml}$ SIM only, (2) in $10 \mathrm{ml}$ SIM supplemented with adenosine $3^{\prime}: 5^{\prime}$ cyclic monophosphoric acid (cAMP-Sigma, $\left.1.53 \times 10^{-3} \mathrm{M}\right),(3)$ in $10 \mathrm{ml}$ SIM supplemented with cAMP $\left(1.53 \times 10^{-3} \mathrm{M}\right)$ and theophylline $\left(10^{-2} \mathrm{M}\right.$, Schwarz/Hann). The SIM was always filtered before the addition of substrate or inhibitor. The sections were dried under a fan before incubation at $37^{\circ} \mathrm{C}$ for $1 \mathrm{hr}$. After rinsing in distilled water, the sections were immersed in dilute ammonium sulphide $(2 \%)$ for $1 \mathrm{~min}$, thoroughly

\section{EXPLANATION OF PLATE 1}

FIG. 1. Cross-section of the cervical region of a 3-day-old mouse showing low cAMP-PD activity. $\times 700$.

FIG. 2. Cross-section of the cervical region of a 3-day-old mouse treated with oestradiol. Note the increased cAMP-PD activity. $\times 700$.

FIG. 3. Cross-section of the cervical region of a 3-day-old mouse showing no 5 '-nucleotidase activity. $\times 700$.

Fic. 4. Cross-section of the cervical region of a 3-day-old mouse treated with oestradiol. Note the increased 5 -nucleotidase activity. $\times 700$. 
PLATE 1
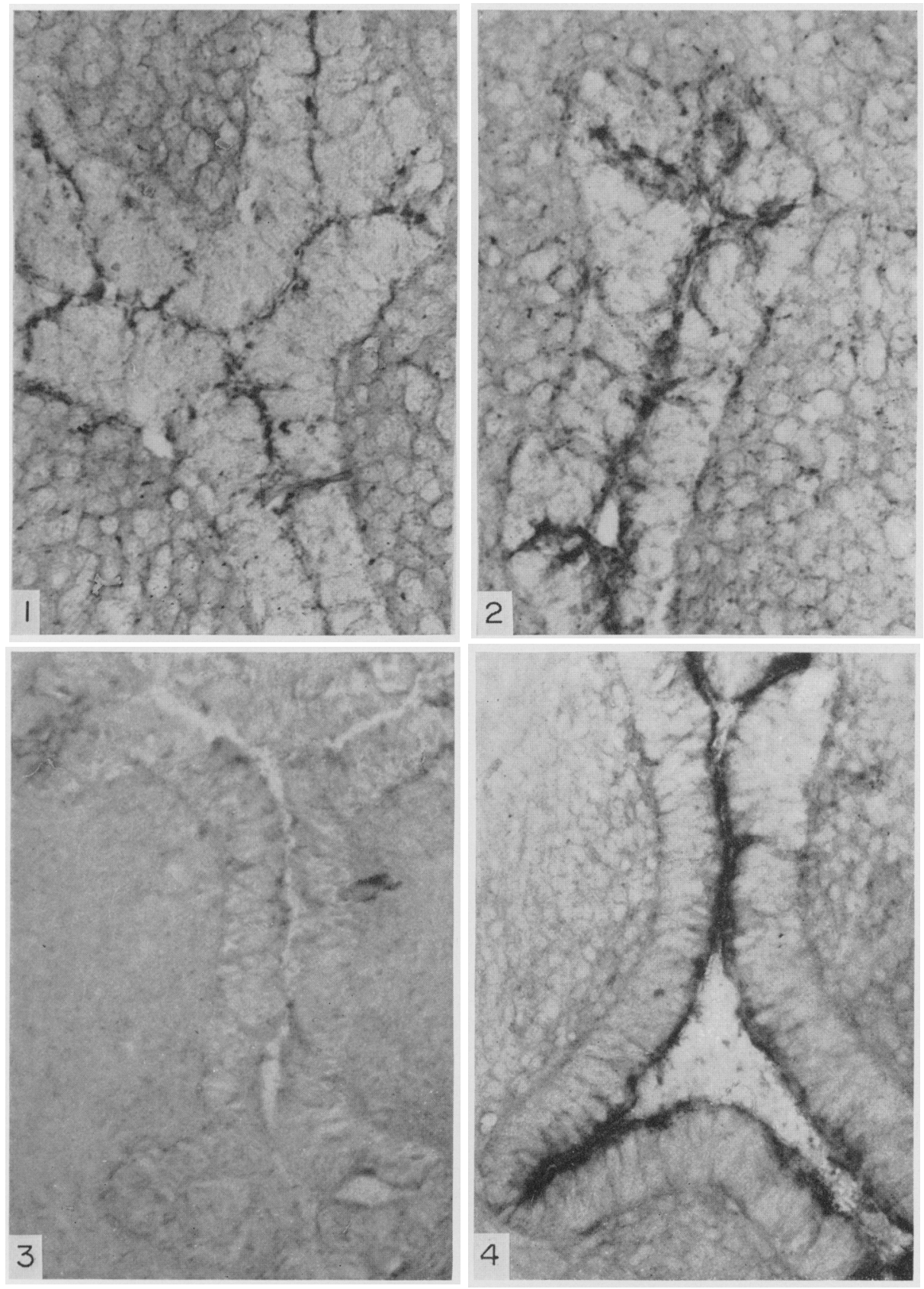

(Fucing p. 136) 
rinsed in distilled water, fixed in $4 \%$ formalin, dehydrated, cleaned, and mounted with Eukitt.

\section{Cytochemical assay of $5^{\prime}$-nucleotidase}

A modified technique of Wachstein \& Meisel (1957) was used as follows: $50 \mathrm{ml}$ of a freshly prepared medium composed of $0.2 \mathrm{M}$-tris-maleate buffer $(\mathrm{pH} 7 \cdot 2)$, magnesium sulphate $(0.1 \mathrm{~m})$, and lead nitrate $(1.8 \mathrm{~mm})$. The sections were divided into two groups: one incubated in the medium supplemented with $3.8 \times 10^{-3} \mathrm{M}-5$ 'AMP (Sigma); the other without 5'AMP. The subsequent processing was identical to that used for phosphodiesterase. Photomicrographs were taken on Kodak film Pan Atomic (16 DIN) within $24 \mathrm{hr}$ after finishing the histochemical procedure.

\section{RESULTS}

cAMP-PD

Activity was present in the most superficial part of the epithelial cells in both the Müllerian vagina and the cervix of 3-day-old control animals. In the newborn, the activity was very slight or absent. After oestradiol injections, there was a slight, but definite, increase in activity in both the regions (Pl. 1, Figs 1 and 2) of 3-day-old animals. The increased activity was most pronounced in the superficial part of the epithelium, where it engaged a broader zone than in the controls. A slight increase was also apparent within the epithelium, where the activity suggested a localization of the enzyme adjacent to the plasma membrane.

In 5-day-old animals, the same localizations of, and the same differences in, activity were found as in the 3-day-old animals. When snake venom was excluded from the SIM, a slight decrease in the amount of lead sulphide deposit was found. No obvious effects were recorded with different concentrations of snake venom. Theophylline reduced the activity of the enzyme, resulting in a slightly visible deposit. Incubation without substrate (cAMP) gave no visible deposit.

Slight activity was found in the surrounding stromal tissue, but this activity was not influenced by age or treatment with oestradiol.

\section{5'-Nucleotidase}

Almost no activity was present in the epithelium of the newborn or the 3-dayold controls. Oestradiol strongly increased the activity in both regions studied (Pl. 1, Figs 3 and 4) in 3-day-old animals. This enzyme also appeared to be localized close to the plasma membrane and to concentrate in the superficial part of the epithelial cells, especially after oestradiol treatment. Incubation without substrate resulted in a complete lack of lead-sulphide deposits.

\section{DISCUSSION}

In experiments designed to study the activity of cAMP-PD, enzyme activity was only seen when substrate in the form of exogenous cAMP was included in the medium. Theophylline, a specific cAMP-PD inhibitor, significantly reduced the activity. Against this background, the observed activity was con- 
sidered specific for CAMP-PD. The slight brown-coloured staining that occurred without using substrate, which was reported by Shanta et al. (1966), and considered by them to be non-specific for phosphodiesterase, was not encountered in our study. The reason for this is not obvious but a tissue-variation might exist regarding the non-specific binding of lead (Ganote, Rosenthal, Moses \& Tice, 1969). Such non-specific tissue binding has also been observed with other divalent cations (Cotran \& Nicca, 1968). Snake venom from Crotalus atrox contains some phosphodiesterase activity (Richards, Vair \& Laskowski, 1965). The amount of this activity, using cAMP as substrate, is obscure, but must be excluded as a cause of activity in our tissue, as the omission of snake venom only slightly reduced the lead sulphide deposit. This also suggests a high endogenous activity of 5'-nucleotidase in this tissue. A non-enzymatic hydrolysis of nucleotides catalysed by lead, as for ATP, is very low for both cAMP and 5'AMP (Moses \& Rosenthal, 1968). The inhibition of rat liver microsomal 5'-nucleotidase by lead has been reported by Widnell (1972). In order to overcome this inhibition, an increased amount of snake venom was used as recommended by Florendo, Barrnett \& Greengard (1971) but its effect was not obvious in our system.

An inverse relation between the activity of $5^{\prime}$-nucleotidase and thymidine incorporation into DNA has suggested that this enzyme may be involved in the degradation of nucleic acids (Hardonk \& Kondstaal, 1967). The importance of $5^{\prime}$-nucleotidase in the degradation of cAMP is not clear, but a sequential degradation of cAMP through $5^{\prime}$-AMP to adenosine is possible. In this connexion, it may be noted that reversion of a cAMP-PD-catalysed reaction is thermodynamically very unfavourable (Cheung, 1972).

The histochemically demonstrable activity of both the enzymes was strictly localized to the most apical part of the epithelial cells, the activity appearing to be related to the luminal plasma membrane. One exception concerned the distribution of cAMP-PD in animals injected with oestradiol, in which the activity was observed in a narrow zone, but still in the most apical part of the cells. The localization of cAMP-PD adjacent to the plasma membrane is consistent with biochemical findings which show an increased yield of enzyme activity after sonication (Thompson \& Appleman, 1971a) and is also consistent with cytochemical (Florendo et al., 1971) and histochemical data (Shanta et al., 1966). The presence of 5'-nucleotidase has been demonstrated in plasma membranes and the endoplasmic reticulum (Widnell, 1972). The occurrence of both the enzymes in the region of the plasma membrane may be correlated with the 'compartmentalization' theory for adenyl cyclase and cAMP-PD (Thompson \& Appleman, 1971b).

The observed increase in activity for cAMP-PD for 3 days after birth correlated well with the appearance of other specific cell functions, such as the production of a specific cervicovaginal antigen, CVA (Forsberg \& Kvinnsland, 1972). The correspondence in localization between enzyme activities and the occurrence of CVA is striking. Both the amount of CVA and the activities of the enzymes increase after injecting animals with oestradiol. In experiments in vitro, exogenous cAMP increases the amount of CVA (Kvinnsland, 1973). There would appear, therefore, to be strong reasons for ascribing an important 
rôle to cAMP in the 'action mechanism' of oestradiol (Fjellestad \& Kvinnsland, 1971; Kvinnsland \& Åbro, 1972; Kvinnsland, 1973). This investigation has shown that cAMP-degrading enzymes are present in the cervicovaginal tissue of neonatal mice, and that the 'action mechanism' of oestradiol involves an effect on the cAMP-level regulating system.

\section{ACKNOWLEDGMENT}

One of us (M.G.H.) held a NORAD postdoctoral fellowship during the course of this work.

\section{REFERENCES}

Cheung, W. Y. (1972) Adenosine 3',5'-monophosphate: on its mechanism of action. Perspect. Biol. Med. $15,221$.

Cotran, R. S. \& NicCA, G. (1968) The intracellular localizations of cations in mesothelium. Lab. Invest. 18, 407.

Fjellestad, D. H. \& Kvinnsland, S. (1971) Immunofluorescence studies on the effect of cyclic adenosine $3^{\prime}, 5^{\prime}$-monophosphate in tissue culture preparations of the cervicovaginal anlage from neonatal mice. Z. Zellforsch. mikrosk. Anat. 121, 69.

Florendo, N. T., Barrnetr, R. J. \& Greengard, P. (1971) Cyclic 3',5'-nucleotide phosphodiesterase: cytochemical localization in cerebral cortex. Science, $\mathcal{N}$. Y. 173, 745.

ForSBERG, J.-G. \& KvinNSLAND, S. (1972) The appearance and distribution of vaginal antigen during the differentiation of the cervicovaginal epithelium in normal and estradiol-treated mice. J. exp. Zool. 180, 403.

Ganote, G. H., Rosenthal, A. S., Moses, H. L. \& Tice, L. W. (1969) Lead and phosphate as sources of artefact in nucleoside phosphatase histochemistry. J. Histochem. Cytochem. 17, 641 .

Hardonk, M. J. \& Kondstaal, J. (1967) 5'-Nucleotidase. II. The significance of $5^{\prime}$-nucleotidase in the metabolism of nucleotides studied by histochemical and biochemical methods. Histochemie, 12, 18.

KvinnsLand, S. (1973) Estradiol-178, cyclic AMP and prostaglandins: in vivo and in vitro studies on the cervicovaginal epithelium from neonatal mice. Life Sciences, Part I, 12, 373.

KvinnsLand, S. \& Abro, A. (1972) Cyclic AMP: its effect on an estrogen-sensitive antigen in organ cultures of the cervicovaginal epithelium from neonatal mice. Experientia, 28, 846.

LAfreniere, R. T. \& Singhal, R. L. (1971) Theophylline-induced potentiation of estrogen action. Steroids, $17,323$.

Moses, H. L. \& Rosenthal, A. S. (1968) Pitfalls in the use of lead ion for histochemical localization of nucleoside phosphatases. $\mathcal{F}$. Histochem. Cytochem. 16, 530.

Richards, G. M., VAIR, G. DU \& Laskowski, M. (1965) Comparison of the levels of phosphodiesterase, endonuclease and monophosphatases in several snake venoms. Biochemistry, 4, 501.

Shanta, T. R., Woods, W. D., Waitzman, M. B. \& Bourne, G. H. (1966) Histochemical method for localization of cyclic 3',5'-nucleotide phosphodiesterase. Histochemie, 7, 177.

Sharma, S. K. \& Talwar, G. P. (1970) Action of cyclic adenosine $3^{\prime}-5^{\prime}$ monophosphate in vitro on the uptake and incorporation of uridine into ribonucleic acid in ovariectomized rat uterus. 7. biol. Chem. 245, 1513.

Szego, G. M. (1971) The lysosomal membrane complex as a proximate target for steroid hormone action. In: The Sex Steroids, pp. 1-51. Ed. K. W. McKerns. Appleton-Century-Grofts, New York.

Szego, G. M. \& Davis, J. S. (1967) Adenosine 3',5'-monophosphate in rat uterus: acute elevation by estrogen. Proc. natn. Acad. Sci. U.S.A. 58, 1711.

Thomas, J. A., Gzap, B., Ling, G. M. \& Singhal, R. L. (1972) Uterine cyclic AMP-H ${ }^{3}$ after estradiol and/or propranolol. Hormone metab. Res. 4, 313.

Thompson, W. J. \& Appleman, M. M. (1971a) Multiple cyclic nucleotide phosphodiesterase activities from rat brain. Biochemistry, 10,311 .

Thompson, W. J. \& Appleman, M. M. (1971b) Cyclic nucleotide phosphodiesterase and cyclic AMP. In: Gyclic AMP and Gell Function, p. 36. Eds. G. A. Robison, G. G. Nahas and L. Triner. New York Acad. Sci.

Wachstein, M. \& Meisel, E. (1957) Histochemistry of hepatic phosphatases at a physiologic pH. Am. F. clin. Path. 27, 13.

WidNels, C. G. (1972) Cytochemical localization of 5'-nucleotidase in subcellular fractions isolated from rat liver. I. The origin of $5^{\prime}$-nucleotidase activity in microsomes. J. Cell Biol. 52, 542. 